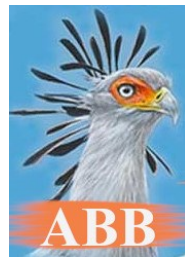

\author{
Afrotropical Bird Biology \\ Journal of the Natural History of African Birds
}

Volume 1

\title{
Vocalizations and song flight of Pink-billed Lark Spizocorys conirostris
}

\section{G Derek Engelbrecht}

\author{
Department of Biodiversity, School of Molecular and Life Sciences, University of Limpopo, Sovenga, South \\ Africa email: faunagalore@gmail.com
}

\begin{abstract}
Pink-billed Lark Spizocorys conirostris is an unobtrusive bird with a relatively low reporting rate of $\sim 10 \%$ in the second South African Bird Atlas Project (SABAP2). Little is known about the species' vocalizations and song flight, and published descriptions are vague or confus-ing. Here I provide a detailed description of vocalizations and song flights as recorded between 2012 and 2019 in Limpopo Province, South Africa. Vocalizations were recorded using a digital recorder for calls in flight and occasionally on the ground, or were obtained from a video camera placed near the nest to record vocalizations that would be impossible to record from a distance. Twelve categories of vocalizations were identified, eight of them described here for the first time. The majority of the eight newly described vocalizations were obtained from video footage. A more detailed description of the song flight is also provided and should clarify some of the confusing descriptions provided in the literature. Knowledge of the flight song of Pink-billed Lark is valuable to locate and identify the species and will be an asset for moni-toring programmes and SABAP2.
\end{abstract}

Keywords: Pink-billed Lark, Spizocorys, Alaudidae, vocalizations, song flight, aerial display, calls Received: 14 September 2020; Accepted 15 September 2020 https://doi.org/10.15641/abb.v1i.1095

\section{Introduction}

Pink-billed Lark Spizocorys conirostris is a southern African near-endemic which extends marginally into Angola and south-western Zambia (de Juana et al. 2004; Dean 2005; Mills 2006). It favours short, open grassy areas, fallow fields or the edges of pans and floodplains in semi-arid to fairly high-rainfall grasslands, or Kalahari vegetation types in the savannah biome (Dean 1997). Its shy and unobtrusive nature means it often goes undetected, resulting in the relatively low reporting rate of $\sim 10 \%$ during the second Southern African Bird Atlas Project (SABAP2) (sabap2.birdmap.africa/species/490).

Although larks are revered as some of the finest songsters amongst birds, this accolade is nearly always based on the song of males performed during their extended aerial display flights known as song flights (de Juana et al. 2004). However, larks are known to have a range of other vocalizations, including alarm, begging, territorial, distress, flight, warning, feeding and flock calls, amongst others, but for most species detailed descriptions of their full vocal repertoire are lacking (de Juana et al. 2004; Donald 2004; Catchpole and Slater 2008). The song flight of Pink-billed Lark is equally poorly known. Descriptions range from 'lacks a distinct aerial display flight' (Allan 2014), to 'a fairly short aerial display' (Ryan 2004) and, perhaps the most detailed, 'an aerial display flight about $20 \mathrm{~m}$ high, calls quietly while cruising' (Vernon 1989).

A comprehensive description of the full vocal repertoire and distinctive song flight of cryptically coloured species such as larks is useful for bird monitoring programmes. For example, the characteristic flight call may aid both the location and identification of an inconspicuous species such as Pink- billed Lark but descriptions of Pink-billed Lark vocalizations in the literature leave much to be desired as it may apply to several of the smaller larks such as Eremopterix spp., Spizocorys spp. and Red-capped Lark Calandrella cinerea (cf. Hockey et al. 2005). Published accounts of Pink-billed Lark vocalizations suggest four types of vocalizations: alarm and flight calls, male song and an unassigned, stridulent-like call, possibly a form of song, produced by birds on the ground (Maclean 1970; Maclean 1985; Ryan 2004; Dean 2005; Peacock 2012).

This study describes the song flight of the Pink-billed Lark and sheds light on the range of other vocalizations.

\section{Methods}

Pink-billed Lark vocalizations were recorded at Al3 Farm, De Loskop $\left(-23.50^{\circ} ; 29.32^{\circ}\right.$; $1090 \mathrm{~m}$ above sea level), approximately $40 \mathrm{~km}$ north of Polokwane, Limpopo Province, South Africa between 2012 and 2019. Incidental observations of song flights of male Pink-billed Larks were recorded during field work when possible. Recordings were made with a Marantz PMD670 Professional digital recorder and a Sennheiser ME66 directional microphone. Some vocalizations were obtained while recording parental activity at the nest using a concealed Sony HDR-XR160 digital video camera placed 1-2 $\mathrm{m}$ from the nest (see Engelbrecht and Marr 2019). Pink-billed Lark is sexually monomorphic and therefore at least one member of the breeding pair was trapped at the nest, sexed using the presence (female) or absence (male) of a brood patch as described by Engelbrecht and Mathonsi (2012), and fitted with a SAFRING metal ring and a combination of colour rings to identify individuals. For the purposes of this study, the following five categories were used to describe the vocal repertoire: elements, syllables, 
phrases, calls and songs (Catchpole and Slater 2008). Elements are the simplest and are often referred to as elementary units and usually defined as a continuous line on a sonogram. A syllable is slightly more complex as it consists of two or more elements lasting a few hundred milliseconds. Several syllables can be grouped together in a particular pattern or they can all be different. Several syllables constitute a phrase and a song sequence comprises several phrases repeated in a variable or repetitive sequence. Calls are basically short, simple sequences of phrases. Sonograms were created using the Raven 1.6.1 software package (Center for Conservation Bioacoustics 2019).

\section{Results}

\section{Vocalizations}

Twelve categories of vocalizations were identified:

\section{Nestling begging call}

These calls were produced by nestlings when they saw a parent flying overhead or arriving at the nest. Begging calls can be either a soft hissing sound, 0.3-0.4 s long, or a highpitched peep call of varying duration (0.1-0.4 s) (Figure 1). Nestling calls were difficult to record as these calls are rather soft and nestlings tend to remain silent when they sense activity near the nest.

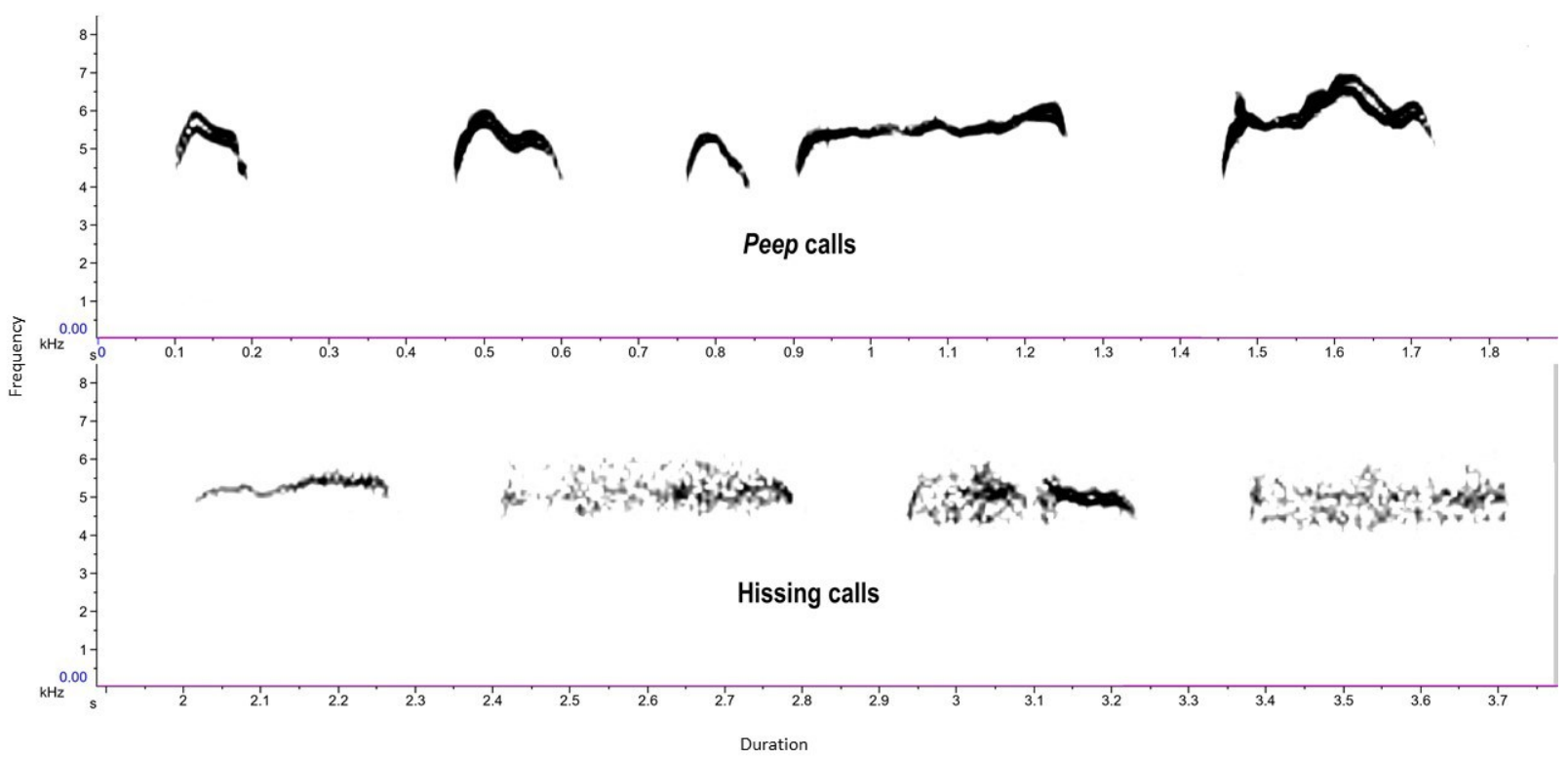

Figure 1: Nestling begging calls of Pink-billed Lark.

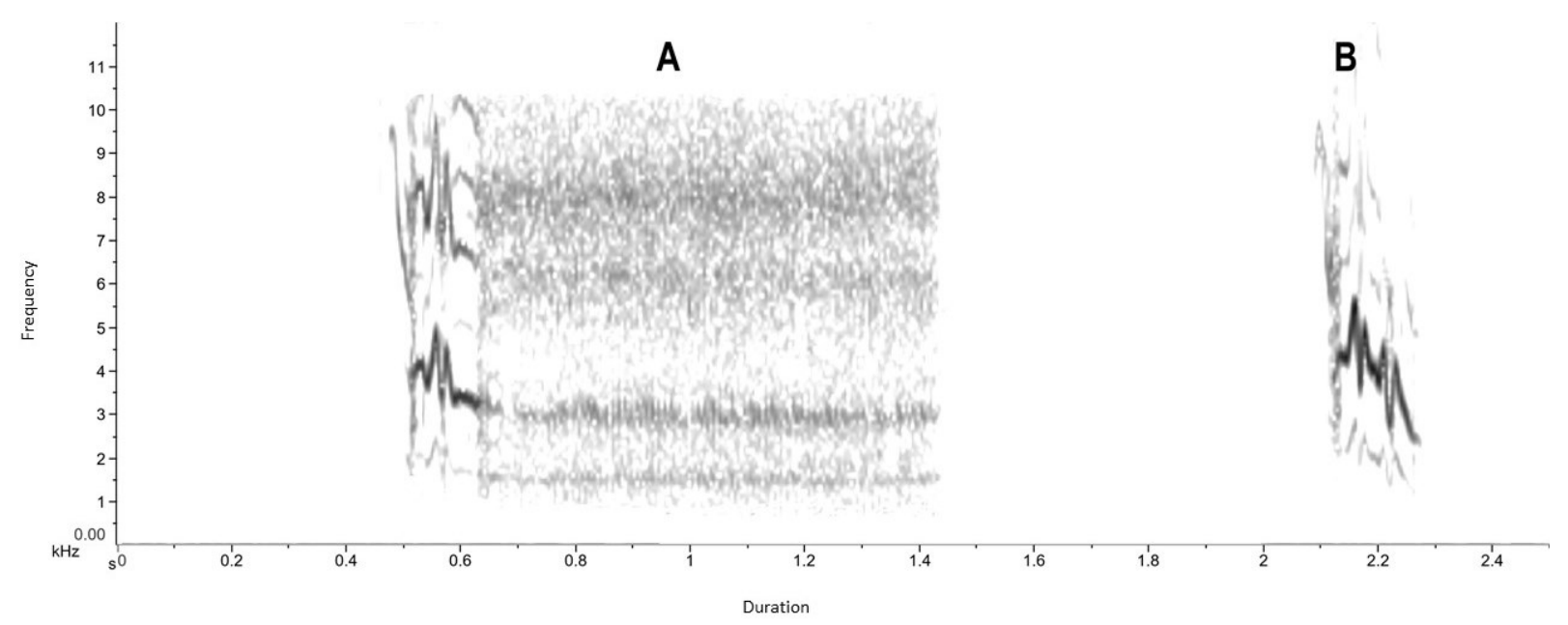

Figure 2. Nestling distress calls of Pink-billed Lark: A - the harsh, drawn-out pulsed call with an introductory shriek note; B - the shriek note on its own. 


\section{Nestling distress/threat call}

These calls were made when the nestlings were handled during data collection. A distress call is characterized by a harsh, drawn-out pulsed call $(0.2-1.0 \mathrm{~s})$ with a broad frequency range, usually preceded by a short, introductory shriek note lasting 0.1-0.3 s (Figure 2). Occasionally, the shriek was called on its own. The pulsed call typically comprised $>50$ elements.

\section{Nestling feeding call}

A soft chi-chi-chi-chi, chirrup or warble of different syllables were called by both sexes when feeding nestlings.

\section{Threat call}

A loud, harsh, grating call comprising 3-5 phrases was documented while video recording activity at a nest. On one occasion, the attending parent raised its back and belly feathers and called a threat call when a centipede passed the nest. On another occasion, one of the nesting pair seemingly attacked what the attending bird perceived as a potential threat that apparently approached close to the nest but the perpetrator was not visible in the video (Figure 3).

\section{Appeasement call}

Apparent appeasement calls were captured while video recording parental activity during incubation. These calls probably serve to reinforce the pair bond and are of two kinds: an excited chattering call (Figure 4) and a very unusual 'metallic' call (Figure 5). The former is a mixture of the flight call of an individual and a warble of individual elements. With the chattering appeasement call, the individual signature flight call syllables are typically delivered at a slightly slower rate compared to the usual flight call, but for much longer periods (typically $>45$ syllables) compared to a flight call. The metallic call is unlike any other lark vocalization known. It is a rapidly pulsed call lasting $0.5-0.7 \mathrm{~s}$, with or without an introductory and/or terminal note. The duration between individual elements may be varied, creating different sound effects.

\section{Alarm call}

This can be described as a pulsed one- or two-phrase call. Alarm calls are characterised by a fluctuation in frequency in the first phrase: it typically has a short, sudden rise in frequency followed by a gradual drop in frequency. Alarm calls

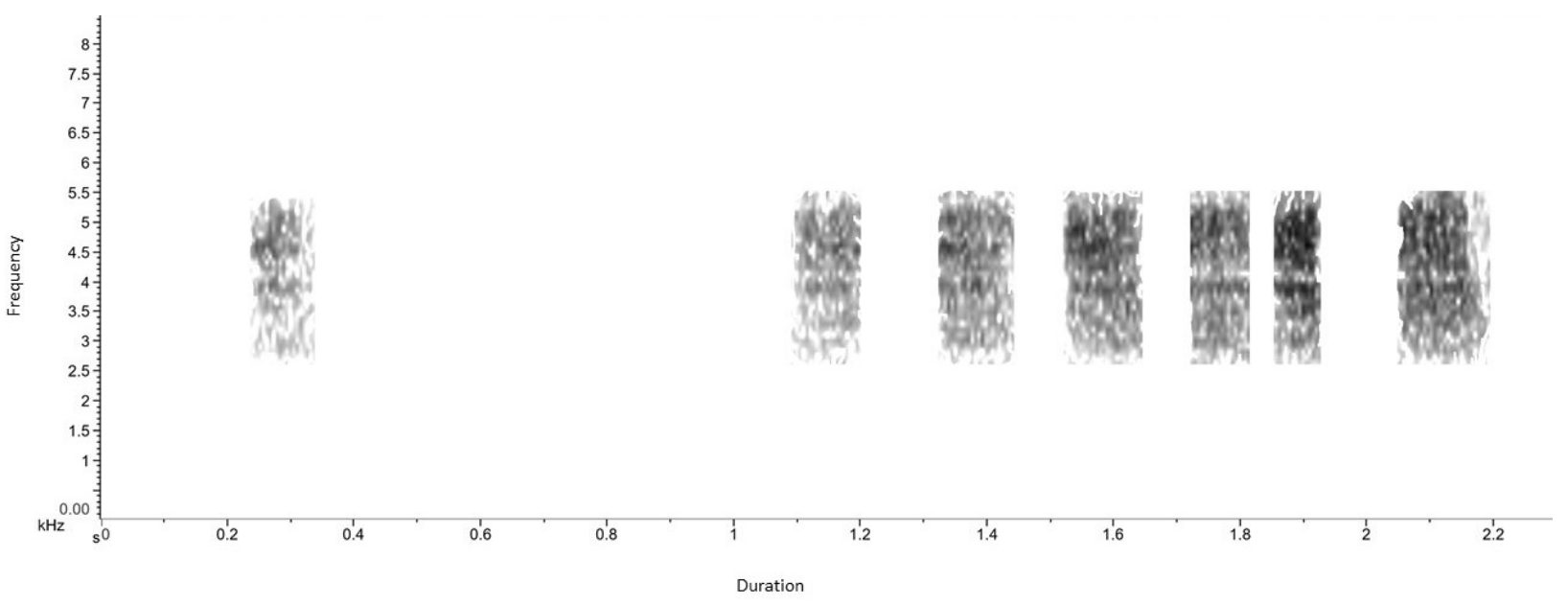

Figure 3. Threat call of Pink-billed Lark.

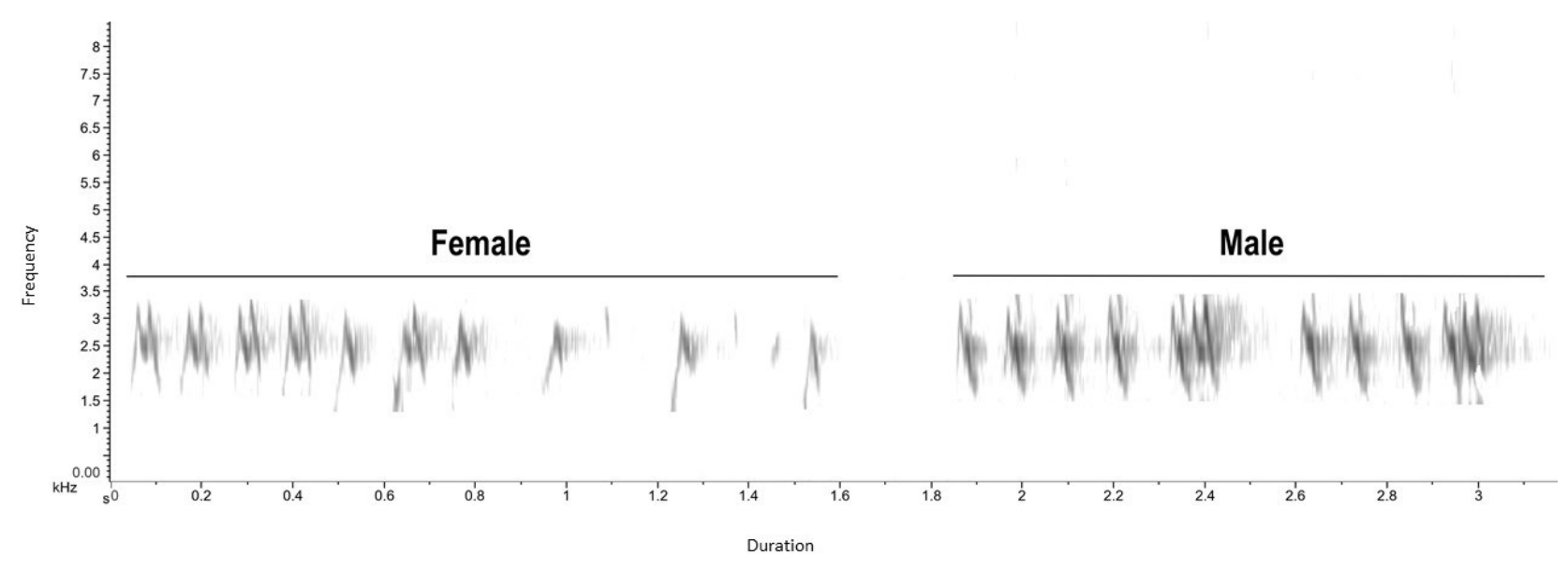

Figure 4. Chattering-type appeasement calls of a pair of Pink-billed Lark at change-over during incubation. 


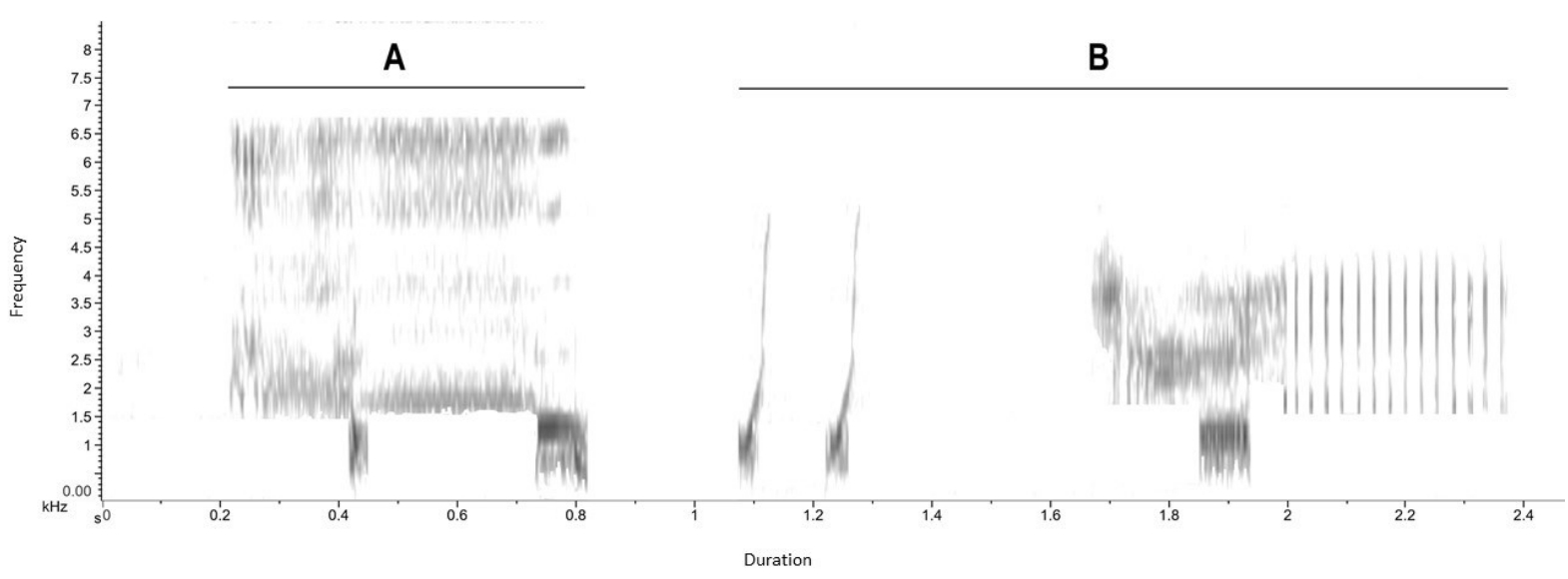

Figure 5. The 'metallic' appeasement call of Pink-billed Lark at change-over during incubation. The sonogram represents two metallic calls: A and B. Call B started with two introductory notes.

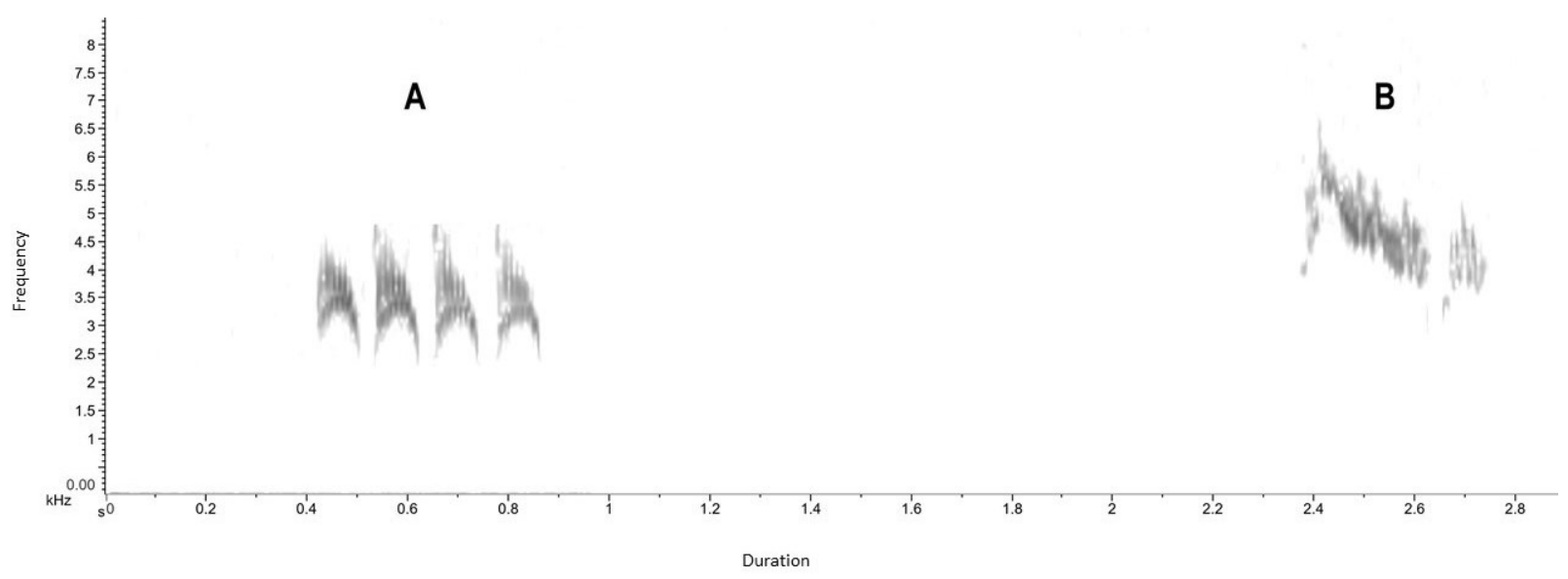

Figure 6. Contact $(A)$ and alarm calls $(B)$ of Pink-billed Lark.

were uttered by both sexes and mostly while in flight as they circled around the area of concern, e.g. when there was disturbance at or near the nest (Figure 6B).

\section{Aggressive/attack call}

This is a rapid tsk call, either a single element or up to 17 clustered together to create a sound resembling electric sparks. This call was occasionally heard when conspecifics chased each other in flight. In such instances it was invariably a 1-2 note tsk call. A more urgent and louder version of this call was recorded on video during an aggressive encounter at an active nest (Figure 7A).

The call preceded an apparent physical approach of the source of the threat.

\section{Cricket call}

This call was recorded on two occasions by birds in flight. It is a soft and very rapid, pulsed call comprising 8-12 elements, the elements separated by approximately $0.01 \mathrm{~s}$ intervals (Figure 7B). Like the aggressive call, the cricket call also resembles a series of electric short circuit sparks or a stridulating insect, e.g. a cricket.

\section{Ground/foraging calls}

A mixed warble of different clicking, tjirp, tek and pulsed kluk calls when birds were foraging on the ground. It is possible that some of these calls may form part of a muted subsong. These calls were generally rather soft and difficult to record (Figure 8).

\section{Flight call}

Flight calls here refers to calls made by both sexes, usually but not exclusively in flight and often when flying in flocks or gathering, e.g. at a source of water. Flight calls were highpitched phrases comprising 2-24 syllables. It appears as if each individual has a unique 'signature' call but this notion needs confirmation (Figure 9).

\section{Song}

The song (or flight song) refers to specific vocalizations made by males only while performing their aerial display flights. This is subtly different to a song flight, i.e. the combination of song and the aerial display flight. Thus, flight song 


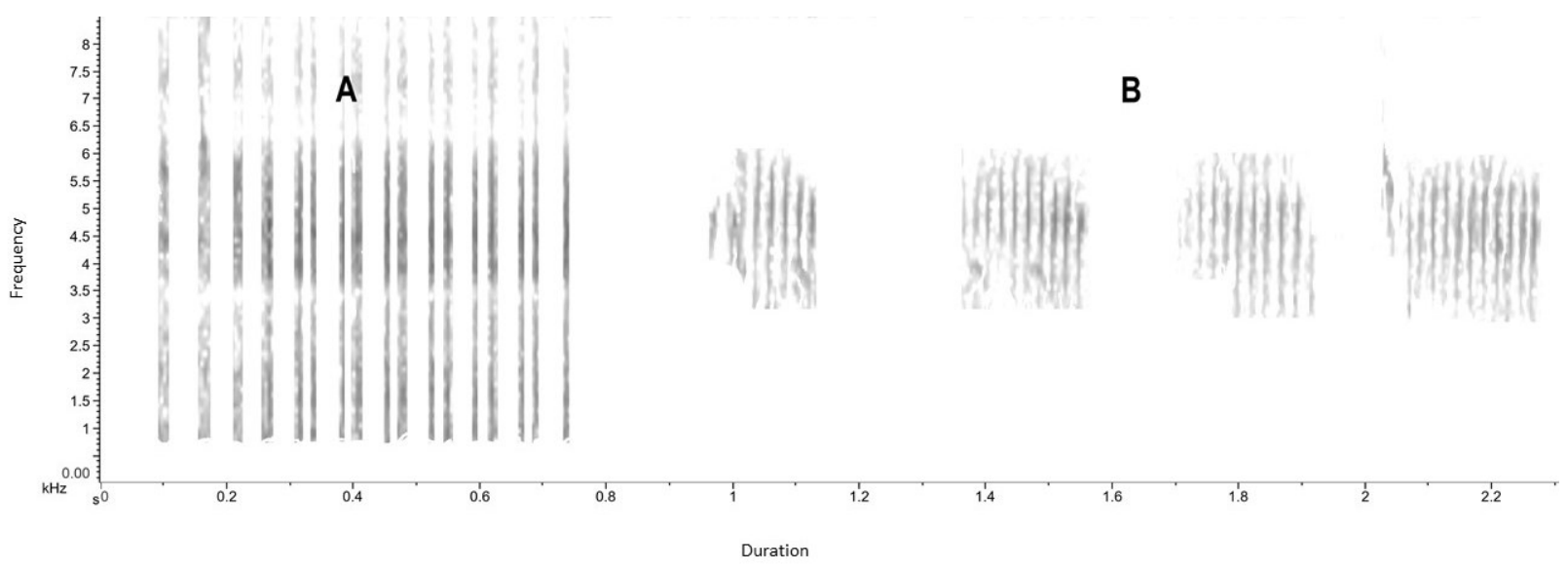

Figure 7. Aggressive (A) and a sequence of four cricket (B) calls of Pink-billed Lark.

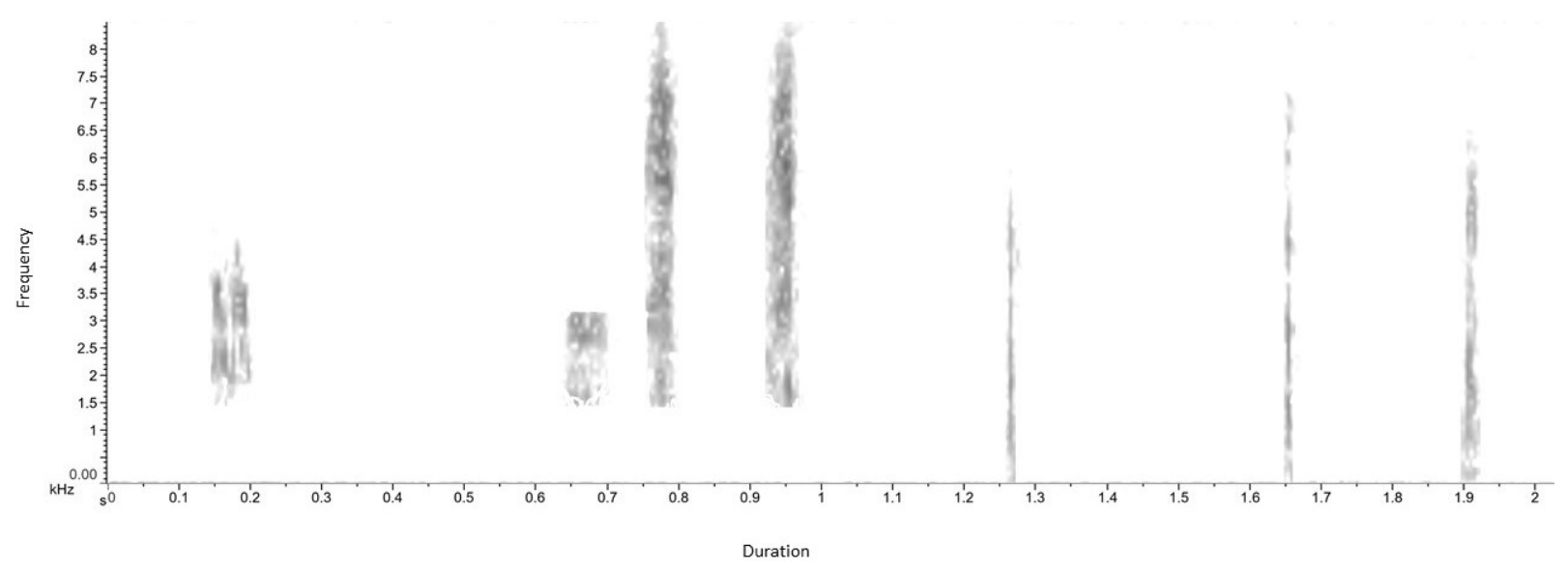

Figure 8. A sequence of various elements and syllables comprising ground calls of Pink-billed Larks.

is a type of vocalization, and song flight refers to an aerial display flight involving male song. The song is a drawn-out, rapid, pulsed call of a constant frequency lasting $\sim 0.4-0.7 \mathrm{~s}$. The sound resembles an object drawn across the teeth of a comb. This call may or may not be preceded by an introductory note or, rarely, a flight-call phrase. An alternative, uncommon form of this call also featured a rapid pulsed call, but comprised two notes; a short one followed by a longer, descending phrase (Figure 10).

\section{Song flight}

Song flights were performed at regular intervals throughout the day and year, albeit most frequently in the morning and just before and during the breeding season. Song flights commenced with a male ascending steeply $\left(>60^{\circ}\right)$ to a height of approximately $15-40 \mathrm{~m}$. The male was usually silent while ascending, although it occasionally started its song towards the end of the ascent. Upon reaching the display height, the male flew in an irregular pattern and alternated between rapid wing fluttering and gliding short distances while singing. Most Pink-billed Lark song flights were short (typically 40-55 s) and the longest song flight observed from start to finish at the study site was $111 \mathrm{~s}$ ( $\mathrm{n}=$ 16). Song flights ended with a steep descent, with wings closed, in a step-wise manner (3-6 steps depending on the initial display height). The steps were sometimes interspersed with short bouts of fluttering flight, and/or song or flight calls as well as acrobatic zigzagging. The final approximately $5-10 \mathrm{~m}$ of the descent were essentially a free fall. Song flights took place over a relatively large area and males sometimes landed in excess of $150 \mathrm{~m}$ from the point of ascent. 


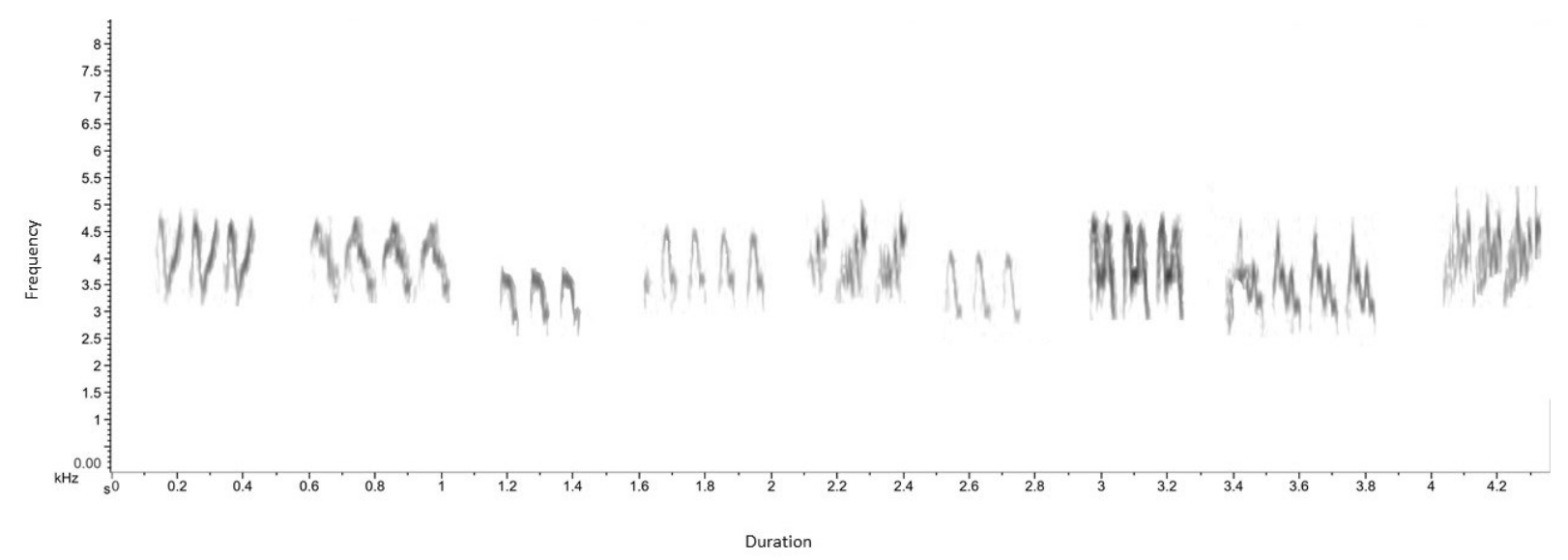

Figure 9. A collage of various flight calls of Pink-billed Lark. Each cluster represents a separate recording, possibly different individuals.

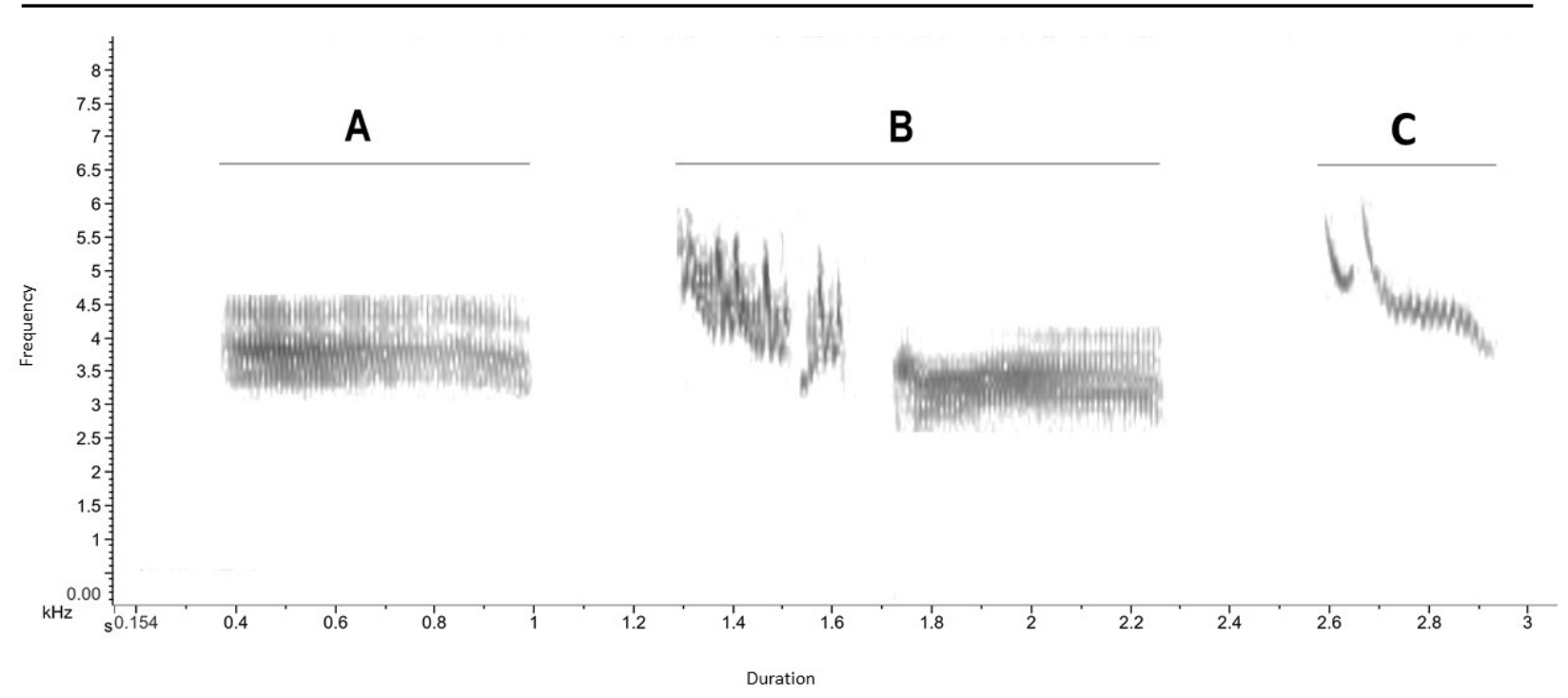

Figure 10. Different kinds of flight songs of Pink-billed Lark: A - the usual drawn-out pulsed call of a constant frequency, B - the same call but with an introductory phrase, $\mathrm{C}-$ an alternative version of the song.

\section{Discussion}

My results reveal a much richer vocal repertoire for Pinkbilled Lark than indicated in the literature. Excluding the two nestling calls, 10 vocalizations were recorded for adults in different behavioural contexts. This is considerably more than the four vocalizations - flight, alarm, ground and song described in the literature. With the exception of the cricket call, all the newly described vocalizations were obtained while video recording behaviour at nests. It is therefore highly unlikely that these 'private' vocalizations will be heard during routine encounters with Pink-billed Lark. These observations, however, yield valuable insight into the complexities of vocal communication in the species.

\section{Vocalizations}

Nestling calls

The nestling begging and distress calls described here are typical of the calls of nestlings of many lark species (Engelbrecht 2005; Engelbrecht and Dikgale 2017; pers. obs.). Although the harsh nature of a distress call serves to startle a potential predator or to alert the parents, video footage and observations made while collecting data active nests suggest a nestling's main defence to a threat remains to tuck into the nest cup and lie motionless, only resorting to the distress call once seized.

\section{Nestling feeding calls}

Nestling feeding calls are used by parents delivering food to nestlings and apparently serve to entice blind nestlings (from hatching to approximately day 3 ) to gape for food. The call is a soft, mixed warble of elements, syllables and short phrases and is similar to the nestling feeding calls of other lark species (Engelbrecht and Dikgale 2017; pers. obs.).

\section{Threat call}

The threat calls recorded during this study are indistinguishable from threat calls of other lark species (pers. obs.). Due to the difficulty in recording threat calls, these calls are likely under-reported in the description of the vocal repertoire of larks. 


\section{Appeasement call}

The appeasement calls recorded in this study probably serve to reinforce the pair bond. These calls were only recorded during incubation at shift change-overs. The chattering call associated with the appeasement calls recorded in this study is similar to some flight calls but has a more excited tone to it and the syllables are repeated for extended periods. In my experience, Peacock's (2012) description of the song flight as a flight call interspersed 'with complex whistles and chattering while flying low over the grass', better fits the appeasement chattering call and behaviour of nesting pairs as observed at change-overs rather than a song flight. For example, when the off-duty parent returns to the nest at a change-over, both sexes call the excited chattering call. Prior to landing, however, the returning bird will often flutter-fly or hover briefly low over the nesting area as if looking to locate the nest before landing.

The metallic appeasement call reported here for the first time is seemingly unique in the family Alaudidae as I have never heard such a call nor could trace a reference to such a call for the family in the literature. It was only heard at change-overs but unfortunately it could not be established which sex performed this call.

\section{Contact call}

This was usually called when the adults were feeling apprehensive about something approaching the nesting area, but this call lacks the urgency of an alarm call.

\section{Alarm call}

According to Maclean (1985) the alarm call is similar to the flight call, but accented in the first syllable. This fits the description of the alarm calls recorded in this study. However, I disagree with Maclean (1985) that it sounds similar to the flight call of the species as it has a distinctly more 'urgent' tone to it and is less musical.

\section{Aggressive/attack call}

The aggressive or attack calls recorded in this study were either recorded during aggressive interactions between conspecifics in flight, or when an unknown threat approached close to the nest. Although this call sounds similar to the cricket call, the duration between elements is longer and it appears to be delivered in groups of two in rapid succession.

\section{Cricket call}

The cricket call reported here is in all likelihood the same as the stridulent-like call reported by Maclean (1970). Although the behavioural context in which it is performed is not known, it may be an alternative manifestation of an aggressive call or form part of the song or subsong of males. In this study, the cricket call was heard during an interaction between three birds, one being a male performing an aerial song flight, the sex of the other two unknown. However, it could not be determined which individual produced the call.

\section{Ground/foraging calls}

Ground calls represent a subdued mixture of various ele- ments, syllables and phrases, and since they are usually performed on the ground and in the presence of another individual, this type of call may represent a version of subsong. Maclean (1970) also described a faint, trrr krik krik call, resembling a stridulating insect, produced by birds on the ground and suggested it represents the audible components of a song. Interestingly, the stridulent call was not listed as one of the calls of the species by Maclean (1985). Maclean's (1970) description of the stridulent calls by birds on the ground may well be the same as the cricket call recorded in this study. Nevertheless, it seems quite possible that the cricket and stridulent calls may be a form of song of Pink-billed Lark which may be delivered on the ground or in flight.

\section{Flight call}

It is clear that the flight call described in this study is similar to the si-si-si, tree-tree-tree or pli-pli-pli flight call described by Maclean (1985) and Peacock (2012). However, this oversimplifies the rich variation in the flight calls of Pink-billed Lark, which possibly reflects differences between individuals. Furthermore, it should be noted that the syllables are delivered in phrases varying from two to as many as 24 syllables, and is not only restricted to bursts of 2- or 3-syllabled phrases as described in the literature. The spectrogram for Pink-billed Lark shown by Maclean (1985) is interpreted here as the species' contact call, not its flight call.

Closer inspection of the flight calls of individuals and observations of nesting birds suggest that each individual has a unique 'signature' flight call. All the other calls reported here, e.g. contact, alarm, ground and aggressive calls, show relatively little intraspecific variation. Pink-billed Larks forage in loose aggregations or flocks and 'universal' calls, e.g. alarm calls, would be advantageous in a flock when a predator is around. However, there are instances where some form of individual recognition would be advantageous, e.g. to locate a mate in a flock, to hear when a mate is approaching the nest or calling from the nest for nest relief.

\section{Song}

Judging by descriptions in the literature, there is considerable confusion regarding the flight song of the Pink-billed Lark. Descriptions range from the absence of a song, to song which is generally inaudible to the human ear, and a host of descriptions that are either vague or simply erroneous (Maclean 1970; Ryan 2004; Peacock 2012). However, the flight song is so distinctive and characteristic of the species that the vague and confusing descriptions in the literature comes as a surprise. It is almost invariably associated with an aerial display flight (only one record of song from the ground recorded in this study) and is often interspersed with flight calls as described in the literature (Ryan 2004; Peacock 2012). I am of the view that the flight calls, which seems to be an individual signature' call as described above, are incorporated into the song to aid in identification of the displaying individual. In my opinion, however, to describe the song as 'short, sweet whistled elements' is incorrect and, although open to interpretation, no calls resembling this description were recorded in this study. The song 
is a rapid, pulsed call lasting approximately $0.5 \mathrm{~s}$ and sounds like an object dragged across the teeth of a comb, interspersed with flight calls. This vocalization is the most reliable indicator of the presence of Pink-billed Lark as it is performed throughout the year and familiarity with it is of particular value in bird monitoring programmes such as the Southern African Bird Atlas Project 2.

\section{Song flight}

Like many larks, Pink-billed Lark also incorporate their song in aerial displays which are characterised by a distinct flying style known as song flights. Despite the brevity of the song flight of Pink-billed Lark (generally $<1 \mathrm{~min}$ ), it is in essence very similar to the aerial display flights of other larks, e.g. Chestnut-backed Sparrow-Lark Eremopterix leucotis with which it co-exists at the study site. Like most other larks, there is a steep ascent, a cruising stage with a butterfly-like flight while singing, followed by a steep descent with the wings closed, either in steps or directly to the ground.

In conclusion, Pink-billed Lark possesses a surprisingly rich vocal repertoire. The study clarified some confusion in the literature regarding the description and behavioural context of some vocalizations and resolved some uncertainty regarding the species' song flight. Although several previously undocumented calls are reported here for the first time, several of these were recorded during video recording sessions at nests and are unlikely to be heard under field conditions. The apparent ability to distinguish individuals based on their flight call merits further investigation.

\section{Acknowledgements}

I wish to express my gratitude to Mr M. Mathonsi for his assistance with locating and observations at some nests.

\section{References}

Allan DG. 2014. Pink-billed Lark. In: Ginn PJ, Mcllleron WG (eds), The ultimate companion for birding in southern Africa, vol. 2. Cape Town: The Unlimited. p. 490.

Catchpole CK, Slater PJB. 2008. Bird song. Biological themes and variations. Cambridge: Cambridge University Press.

Center for Conservation Bioacoustics. 2019. Raven Pro: Interactive sound analysis software (version 1.6.1.) [Computer software]. Inthaca, NY: The Cornell Lab of Ornithology. Available from http://www.birds.cornell.edu/raven.

Dean WRJ. 1997. Pink-billed Lark Spizocorys conirostris. In: Harrison JA, Allan DG, Underhill LG, Herremans M, Tree AJ, Parker V, Brown CJ (eds), The atlas of southern African birds, vol. 2: Passerines. Johannesburg: Birdlife South Africa. pp. 34-35.

Dean WRJ. 2005. Pink-billed Lark. In: Hockey PAR, Dean WRJ, Ryan PG (eds), Roberts birds of southern Africa (7th edn). Cape Town: The Trustees of the John Voelcker Bird Book Fund. pp. 887-888.

de Juana E, Suárez, F, Ryan PG. 2004. Family Alaudidae (Larks). In: del Hoyo J, Elliot A, Christie DA (eds), Handbook of the birds of the world, vol. 9: Cotingas to pipits and wagtails. Barcelona: Lynx Edicions. pp. 496-601.

Donald PF. 2004. The skylark. London: T \& AD Poyser Publishers.

Engelbrecht GD. 2005. Breeding biology of the eastern population of the Short-clawed Lark. Ostrich 76: 97-104.

Engelbrecht D, Mathonsi MHL. 2012. Breeding ecology of the pinkbilled lark, Spizocorys conirostris, in an agricultural landscape in South Africa. African Zoology 47: 26-34.

Engelbrecht D, Dikgale ML. 2017. Display and vocalizations of the Chestnut-backed Sparrowlark. Honeyguide 63: 35-42.

Engelbrecht GD, Marr SM. 2019. Parental care in a sexually monomorphic, ground-nesting passerine, the Pink-billed Lark Spizocorys conirostris (Alaudidae). Ostrich 90: 247-256.

Hockey PAR, Dean WRJ, Ryan PG (eds). 2005. Roberts birds of southern Africa (7th edn). Cape Town: The Trustees of the John Voelcker Bird Book Fund.

Maclean GL. 1970. Breeding behaviour of larks in the Kalahari sandveld. Annals of the Natal Museum 20: 381-401.

Maclean GL. 1985. Roberts birds of southern Africa (5th edn). Cape Town: The Trustees of the John Voelcker Bird Book Fund.

Mills MLS. 2006. First record of Pink-billed Lark Spizocorys conirostris for Angola. Bulletin of the African Bird Club 13: 212.

Peacock F. 2012. LBJs. Pretoria: Mirafra Publishing.

Ryan PG. 2004. Pink-billed Lark. In: del Hoyo J, Elliot A, Christie DA (eds), Handbook of the birds of the world, vol. 9: Cotingas to pipits and wagtails. Barcelona: Lynx Edicions. pp. 591-592.

Vernon CJ. 1989. Pinkbilled Lark. In: Ginn PJ, Mcllleron WG, Milstein PleS (eds), The complete book of southern African birds. Cape Town: Struik-Winchester. p. 426.

Afrotropical Bird Biology (ABB) is a free, open-access, online journal for articles that describe aspects of the natural and cultural history of birds in the Afrotropical region, including its offshore islands. These include, but are not restricted to, identification features, sounds, distribution and demography, movements, habitats, diseases and parasites, general habits, foraging and food, breeding, interactions with humans, human cultural beliefs and practices as they pertain to birds, moult and biometrics of birds. ABB publishes original contributions focused on presenting information about the natural history of Afrotropical birds. This includes short communications $(<2500$ words, including references) and data papers. All contributions will be reviewed by at least one editor and external, independent referees may also be employed at the discretion of the editors.

All papers are published under the Attribution-NonCommercial CC BY-NC license, which lets others remix, adapt, and build upon your work non-commercially, and although their new works must also acknowledge you and be non-commercial, they don't have to license their derivative works on the same terms.

https://journals.uct.ac.za/index.php/ABB 